elementary account of the subject that is as accurate or as comprehensive as his. I suspect that most students who emerge victorious from this tough assignment will tacitly conclude that they share a common scientific psychology, even motivation, with those whose methods they can now so well understand. In this they are likely to be mistaken, but the fact that the inference is partly right is what makes Evans' book so educationally important.

J. D. North is at the Philosophical Institute,

University of Groningen, A-Weg 30,

9718 CW Groningen, The Netherlands.

\section{The laying on of genes}

The Development of Human Gene Therapy: Monograph 36

edited by Theodore Friedmann

Cold Spring Harbor Laboratory Press: 1999.

729 pp. $\$ 134$

\section{KarolSikora}

The transfer of specific genetic material to treat disease has been one of the most exciting potential applications of modern genetics. Given the complexity of the task, it is perhaps not surprising that progress has been slow in terms of clinical gain. The main stumbling block right from the start has been in getting DNA to the right place in a form that permits its expression at the right time in enough cells. The problem of effective in vivo gene targeting still bedevils the field a decade after the first trials began.

The collection of reviews in The Development of Human Gene Therapy begins with a historical overview going back to Archibald Garrod, the senior physician at St Bartholomew's Hospital, London, who, around the turn of the century, discovered what he termed the "inborn errors in metabolism". It covers the abortive and potentially unethical beginnings of human globin-gene transfer for thalassaemia in the early 1970s, when globin genes were introduced into the bone marrow cells of two patients. Gene expression was unlikely, and no ethical approval had been obtained. The first successes came with cystic fibrosis, adenosinedeaminase deficiency and cancer. Success, of course, is only relative. Real success equates with clinical benefit in terms of improved quality of life or increased survival, and this has so far proved elusive.

The chapters on the major vehicles for gene delivery cover retroviruses, adenoviruses, herpes viruses, lentiviruses, a range of more unusual vectors and, of course, physical delivery systems. Much of the information is dreadfully old and can be found in greater detail elsewhere. Although the major targets for clinical exploitation are discussed, it seems strange to omit the remarkable clinical developments in cystic fibrosis, ischaemic heart disease and the rare single-gene disorders. Some clinical possibilities that are now the focus of much currrent activity, such as arthritis, retinopathies, collagen disorders, asthma, diabetes and obesity, are not even mentioned.

Highlights of this large volume include an excellent chapter on naked DNA injection into various tissues. The fact that this leads to gene expression at all is remarkably encouraging for the future. Another chapter considers targeted gene repair in mammalian cells using chimaeric oligonucleotides. Although a long way from the clinic, this represents the beginnings of genetic surgery. The short review on stem-cell transplantation is concise, yet informative, while the ethics of the subject are well reviewed in a historical context.

There are several excellent short books reviewing gene therapy. Unfortunately, this is not one of them; its content is outdated and the artwork incredibly poor, and, a major criticism, despite the encyclopaedic coverage of the field, the material comes almost exclusively from US-based authors. Human-gene therapy is now an international endeavour, with clinical protocols in place in more than 25 countries. True, the Americans got there first, but please, the rest of the world does exist.

Karol Sikora is at the World Health Organization

Cancer Programme, International Agency for

Research on Cancer, 69372 Lyon, France.

\section{Genetics of another animal}

The Zebrafish: Biology (Methods in Cell

Biology Vol.59)

edited by H. William Detrich III,

Monte Westerfield and Leonard I. Zon

Academic:1998. \$64.95

\section{An explosive laboratory}

\section{Island Biogeography: Ecology, Evolution and Conservation}

by Robert J. Whittaker

Oxford University Press: 1998. 285 pp.

E19.99, \$29.95 (pbk)

\section{illkkaHanski}

The island of Krakatau in the Sunda strait was reduced to one-third of its size by violent volcanic eruptions on 27 August 1883. Remains of unlucky life were buried under 60-80 metres of ash, but, luckily for science, the biologists of the time were quick to grasp the unique opportunity for observing recovery.

Within a few years, coastal plant communities were well established. The interior was first colonized by ferns and grasses, to be replaced by forest within 40 years. So far, more than 300 plant species have been recorded from Krakatau, although there are fewer species there today - many species recorded in the past have become extinct. Animals present much the same picture. For instance, the cumulative number of bird species is nearly 50 , whereas the present bird community has some 30 species.

Robert Whittaker's Island Biogeography delivers a sweeping lesson in island ecology enhanced by the author's long-term involvement in the research on Krakatau. Intriguingly, bird colonization of Krakatau also featured as the opening example in the trail-blazing island-ecology book of the century, Robert H. MacArthur and E. O. Wilson's The Theory of Island Biogeography (Princeton University Press). Back in 1967, these authors concluded that the number of bird species had reached an equilibrium by the 1930s, although further extinctions and colonizations of individual species were to be expected. In the graph shown by Whittaker, the number of bird species has increased only slightly since the 1930s. Some extinctions and colonizations are attributed to successional changes in the island's vegetation rather than to stochastic factors.

One might think that the latest figures endorse MacArthur and Wilson's prediction, but Whittaker takes the opposite view. In fact, by his judgement the MacArthurWilson theory is essentially dead, as islands are ceaselessly bombarded by disturbances - though Krakatau may be an extreme example - and there is therefore no time for an equilibrium to become established. The 'island theory' is replaced by 'disturbed island ecology', without the word 'theory' in the latter label.

Whittaker's conclusion is curious, since it is akin to asserting that density-dependent population regulation is unimportant because population sizes are perturbed by varying environmental conditions. True, an equilibrium in the sense of a constant number of individuals in a population, or of species on an island, is unlikely, but equilibrium in the sense of a characteristic distribution of numbers in the course of time may well occur. What matters are the processes.

Island Biogeography covers the full range of topics, from the geography and geology of islands, their speciation and evolution, population ecology and community assembly, to the application of island theory to conservation. Although islands in the sea account for only $3 \%$ of Earth's land area, and individual islands have impoverished communities, the pooled number of species on islands is great. For example, around 15\% of all known species of birds and plants occur on islands. Islands are ecological and evolutionary laboratories. Whittaker describes cases of 
adaptive radiation on islands, patterns in the adaptation to island life, assembly of island communities - and sad stories of the demise of unique island life brought about by humans and human companions from the mainlands.

As islands have a limited area, island populations have a limited size. One fascinating topic that Whittaker does not discuss probably for lack of primary research - is the question of the survival and evolution of small populations on islands. Have some island populations the means of surviving in spite of small population size, and if so, what are these means?

Island Biogeography will satisfy those looking for a comprehensive text on island ecology, but it offers no surprises. Whittaker's 'disturbed island ecology' does not really take off. Nature is complex, but merely exposing complexity is not enough - I will keep wiping the dust off my copy of The Theory of Island Biogeography. Ilkka Hanski is in the Department of Ecology and Systematics, PO Box 17 (Arkadiankatu 7), FIN-00014, University of Helsinki, Finland.

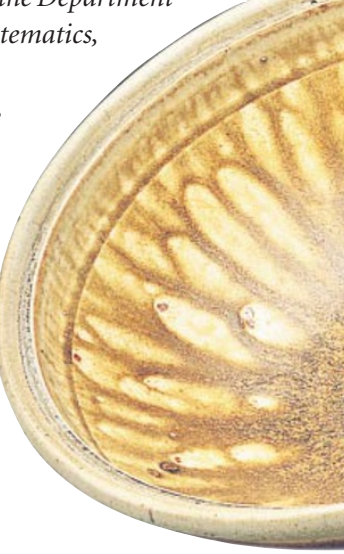

\section{New Journals}

This year, Nature's annual New Journals review supplement will appear in the issue of 2 September. Publishers and learned societies are invited to submit journals for review, as well as details of any eligible electronic journals, taking note of the following criteria:

- Journals must have first appeared during or after June 1997 and issued at least four separate numbers by the end of May 1999.

- Journals covering any aspect of science are eligible, although those dealing with clinical medicine and pure mathematics are excluded, as are newsletters and publications of abstracts.

- Frequency of publication must be at least three times a year.

- The main language must be English.

- Deadline for submission is 28 May.

Please send at least four different issues (the first, the most recent and any two others) of each eligible title, together with full details of subscription rates, to: Isobel Flanagan, Nature, Porters South, Crinan Street, London N1 9XW, UK. Tel: +44 (0)171 843 4542. e-mail: i.flanagan@nature.com

\section{Science in culture}

\section{Glazes from deep time}

The ceramic imagery of Joan Lederman Martin Kemp

C eramic vessels have borne profound meaning for many cultures and civilizations, and are not merely functional objects that, at their best, aspire to a modest kind of beauty. In modern Western culture a pot tends to be a pot, and the person who makes it a potter, a craftsperson. Joan Lederman calls herself a "potter and imagineer". The extended title is well deserved; she is creating a form of ceramic art that resounds thrillingly across time and space.

On 16 July 1996, Chris Griner, an able-bodied seaman in the palaeoclimate research team at the Woods Hole Oceanographic Institution on Cape Cod, brought to Lederman's "The Soft Earth" studio a bucket of sediment raised from the Atlantic floor east of Virginia (latitude $32^{\circ}$ $21^{\prime} \mathrm{N}$, longitude $68^{\circ} 50^{\prime} \mathrm{W}$ ) at a depth of $4,500 \mathrm{~m}-$ some two miles. Fired in her kiln at $1,100^{\circ} \mathrm{C}$, lavalike, it congealed. Three months later, Lederman experimented with the mud as a glaze for stoneware vessels. Thinned gently with water but otherwise unmodified and applied evenly over the clay bodies, the fired sediments wondrously metamorphosed from a uniform layer into modelled patterns and beguiling arrays of colour.

A series of experiments followed in a new, hotter kiln using mud not only from the waters around the United States but also from such farflung sources as the Arabian and Indian Oceans, the latter found by carbon dating to be 35-40 million years old. The example illustrated, which used sediments brought back to Woods Hole by the research vessels Knorr and Oceanus, shows how the resulting glazes "seem to have a life of their own - like a fingerprint". While the "glazes that humans have concocted are often exquisite ... they have a different voice. They are more contrived from nature than they are released by nature."

Lederman sees herself as "a channel for what the sea muds might do ... I adjust the form, the application, the thickness, the claybody, the firing, the juxtaposition to other glazes, to make what could happen actually emerge."
What emerges, most notably with sediments that are dense in foraminifera, as on the inside of the bowl, are beautiful variations on dendrite formations, seemingly rising and ramifying, brought, from within the inferno of Lederman's kiln, to new life after aeons of remote stillness in the depths of the sea. On one level, we can see the results as beguiling examples of the potter's art, but on another they carry an extraordinary frisson. To cradle one of Lederman's vessels in one's hands is an evocative, even eerie experience, akin to holding a fragment of meteorite or peering at a sample of Moon rock.

Visually, the emergent patterns resonate with the dendritic forms that comprise one of the recurrent organizational configurations in nature, ranging from roots of nerve cells to river deltas. And they can now be modelled on computer through diffusion-limited aggregation, in which particles in Brownian motion adhere successively around a fixed particle to generate fern-like radiations.

Lederman is knowingly leaving the field for perception and interpretation open, creating "holistic experiences that call people to the learning that is alive for them". But in her collaboration with the ancient muds that hold the secrets of palaeontological climates, she is actively inducing us to share her sense of wonder at the way earth, fire and water - the very stuff of the potter's art - speak of elemental forces that have repeatedly attracted human creators across distant times and spaces.

Joan Lederman's ceramics can be seen in the New England Aquarium, Boston, Massachusetts 02110, USA, and at

http:/ / www.arts-cape.com/softearth/ Martin Kemp is in the Department of the History of Art, University of Oxford, 35 Beaumont Street, Oxford OX1 2PG, UK.

Inner and outer views of the North Atlantic Deep Sea Bowl, glazed with sediments recovered by the research vessels Knorr and Oceanus, July 1998. 